\title{
Nitrogen effects on seed germination and seedling growth
}

\author{
THOMAS A. MONACO, CHARLES T. MACKOWN, DOUGLAS A. JOHNSON, THOMAS A. JONES, JEANETTE \\ M. NORTON, JAY B. NORTON, AND MARGARET G. REDINBAUGH
}

\begin{abstract}
Authors are Ecologist, USDA-ARS Forage and Range Research Lab., Utah State Univ., Logan, Utah 84322-6300; Plant Physiologist, USDA-ARS Grazinglands Research Lab., El Reno, Okla. 73036-2144; Plant Physiologist and Plant Geneticist, USDA-ARS Forage and Range Research Lab., Utah State Univ., Logan, Utah 84322-6300; Associate Professor, Plants, Soils, and Biometeorology Department, Utah State Univ., Logan, Utah 84322-4820; Postdoctoral Research Associate, Plants, Soils, and Biometeorology Department, Utah State Univ., Logan, Utah 84322-4820, and Molecular Geneticist, USDA-ARS Corn
\end{abstract} and Soybean Research, Wooster, Ohio 44691-4096.

\section{Abstract}

Recent evidence associates the persistence of invasive plant species with disturbance and fluctuations in distinct forms of mineral $\mathbf{N}$ in soils. We conducted soil and hydroponic experiments to investigate the influence of $\mathbf{N}$ form and availability on germination and seedling development of 2 invasive annual grasses, cheatgrass (Bromus tectorum) and medusahead (Taeniatherum caput-medusae) and 6 perennial grasses, bluebunch wheatgrass (Pseudoroegneria spicata), crested wheatgrass (Agropyron cristatum $\times$ A. desertorum), Sand Hollow and Seaman's Gulch big squirreltail (Elymus multisetus), and Little Camas and Little Wood bottlebrush squirreltail (E. elymoides ssp. brevifolius and $E$. elymoides ssp. elymoides, respectively). Seeds were sown in soils with no soil additions, barley straw (1 $\left.\mathrm{mg} \mathrm{kg}^{-1}\right), \mathrm{NH}_{4}^{+}=10 \mathrm{mg} \mathrm{N} \mathrm{kg}^{-1}, \mathrm{NH}_{4}^{+}+\mathrm{I}$ (nitrification inhibitor) $=10 \mathrm{mg} \mathrm{N} \mathrm{kg}^{-1}+37 \mathrm{ml}$ nitrapyrin, or $\mathrm{NO}_{3}^{-}=10 \mathrm{mg} \mathrm{N} \mathrm{kg}^{-1}$ to evaluate cumulative germination percentage for 20 days in an incubator. For the hydroponic experiment, grass seedlings were exposed to distinct forms and uniform concentrations of mineral $\mathbf{N}$ to monitor root and shoot growth for 21 days. Treatments were no $\mathrm{N}$ added, $\mathrm{NH}_{4}{ }^{+}(1 \mathrm{mM}), \mathrm{NO}_{3}^{-}(1 \mathrm{mM})$, and $\mathrm{NH}_{4} \mathrm{NO}_{3}(0.5$ $\mathrm{mM}$ ). Treatments did not alter germination in the soil experiment. Lack of soil $\mathbf{N}$ effect on seed germination is attributed to the absence of seed dormancy in the populations of grasses we evaluated. Initial root length and overall shoot growth of grasses were greater in the $\mathrm{NO}_{3}{ }^{-}$than in the $\mathrm{NH}_{4}{ }^{+}$treatment more frequently for perennial grasses. Root and shoot growth of medusahead and cheatgrass generally exceeded that of the other grasses except crested wheatgrass. However, relative decreases in root dry mass for the no $\mathbf{N}$ treatment were greater for the invasive annual grasses than the perennial grasses when compared to the $\mathrm{N}$-addition treatments.

Key Words: perennial grass, invasive annual grass, seedling establishment, nitrate, ammonium, root growth

Many shrub-steppe plant communities of the Intermountain West have been replaced by the invasive annual grasses cheatgrass (Bromus tectorum L.) and medusahead (Taeniatherum

Research was funded by USDA-ARS and USDA-CSREES Grant No. 9738300-4892. We extend appreciation to Kevin Connors for his critical assistance in developing the design and attentive execution of the soil experiments. We also thank Justin Williams, Brandon Gordon, Jacqueline Adams, Tyler Sorensen, and Brandy Jones for assisting with seed and data collection. Drs. T. Svejcar and U. Choromanska provided helpful reviews on a previous draft of this manuscript.

*Corresponding author Monaco (tmonaco@cc.usu.edu)

Manuscript accepted 2 Feb. 03.

\section{Resumen}

Evidencia reciente asocia la persistencia de especies de plantas invasoras con el disturbio y las fluctuaciones de las distintas formas de $\mathbf{N}$ mineral de los suelos. Condujimos experimentos en suelo e hidroponía para investigar la influencia de la forma del $\mathbf{N}$ y su disponibilidad en la germinación y desarrollo de plántulas de 2 zacates anuales invasores "Cheatgrass" (Bromus tectorum) y "Medusahead" (Taeniatherum caput-medusae) y 6 zacates perennes "Bluebunch wheatgrass" (Pseudoroegneria spicata), "Crested wheatgrass" (Agropyron cristatum x A. desertorum), "Sand Hollow", "Seaman's Gulch big squirreltail" (Elymus multisetus), "Little Camas" y "Little Wood bottlebrush squirreltail" (E. elymoides ssp. brevifolius y E. elymoides ssp. elymoides, respectivamente). Las semillas fueron sembradas en suelos si adiciones de suelo, paja de cebada $\left(1 \mathrm{mg} \mathrm{kg}^{-1}\right), \mathrm{NH}_{4}^{+}=10 \mathrm{mg} \mathrm{N}$ $\mathrm{kg}^{-1}, \mathrm{NH}_{4}{ }^{+}+\mathrm{I}$ (inhibidor de nitrificación) $=10 \mathrm{mg} \mathrm{N} \mathrm{kg}+37 \mathrm{ml}$ nitrapirin o $\mathrm{NO}_{3}^{-}=10 \mathrm{mg} \mathrm{N} \mathrm{kg}^{-1}$ para evaluar el porcentaje acumulativo de germinación durante 20 días en una incubadora. En el experimento hidropónico las plántulas de zacate fueron expuestas a distintas formas y concentraciones uniformes de nitrógeno mineral para monitorear el crecimiento de raíz y tallo durante 21 días. Los tratamientos fueron: No adición de $\mathrm{N}$, $\mathrm{NH}_{4}{ }^{+}(1 \mathrm{mM}), \mathrm{NO}_{3}^{-}(1 \mathrm{mM})$ y $\mathrm{NH}_{4} \mathrm{NO}_{3}(0.5 \mathrm{mM})$. Los tratamientos no alteraron la germinación en el experimento realizado con suelo, la falta de efecto del $\mathbf{N}$ del suelo en la germinación de la semilla se atribuye a la ausencia de dormancia de la semilla de las poblaciones de zacates que fueron evaluadas. La longitud de la raíz inicial y el crecimiento general del tallo de los zacates fue mayor en el tratamiento de $\mathrm{NO}_{3}^{-}$que en de $\mathrm{NH}_{4}{ }^{+}$, esto se presentó más frecuentemente en los zacates perennes. El crecimiento de raíz y tallo en el "Medusahead"y “Cheatgrass"generalmente excedió el alcanzado por los otros zacates, excepto el "Crested wheatgrass". Sin embargo, las disminuciones relativas de la biomasa seca de la raíz en el tratamiento sin aplicación de $\mathbf{N}$ fue mayor para los zacates invasores que para los zacates perennes cuando se compararon con los tratamientos de adición de $\mathrm{N}$.

caput-medusae [L.] Nevski). Re-establishing perennial grasses by seeding semi-arid rangelands is challenging because these invasive annual grasses have higher reproductive potentials (Mack and Pyke 1983, Young 1992), more persistent seed banks (Hassan and West 1986, Humphrey and Schupp 2001), and higher growth rates (Arredondo et al. 1998) than most perennial grasses. Consequently, there is tremendous need to develop soil and seedbed treatments to improve germination, emergence, and early seedling growth of desirable perennial species. 
Recent evidence strongly associates the persistence of invasive plant species and the loss of native species with disturbance and fluctuations in soil fertility (Huenneke et al. 1990, Burke and Grime 1996, Davis et al. 2000). The addition of mineral $\mathrm{N}$ to disturbed rangelands has been found to increase the relative abundance of cheatgrass, while reductions in $\mathrm{N}$ availability generally increased the relative abundance of perennial species (Paschke et al. 2000). Young et al. (1995, 1998) found seedling establishment of medusahead increased with $\mathrm{NO}_{3}{ }^{-}$fertilization, was unaffected by $\mathrm{NH}_{4}{ }^{+}$fertilization, and decreased when mineral $\mathrm{N}$ was immobilized. These field experiments suggest that modifications in soil $\mathrm{N}$ availability and mineral $\mathrm{N}$ form may decrease establishment of invasive annual grasses. However, it is unclear whether these soil modifications will impact desirable perennial grasses frequently seeded in the Intermountain West.

The goal of our study was to evaluate the influence of $\mathrm{N}$ form and availability on germination and early seedling development of cheatgrass, medusahead, and 3 perennial grass species. With favorable precipitation, most seeds of cheatgrass and medusahead germinate the year they are produced, and seeds of the perennial grasses are typically non-dormant when utilized for seeding rangelands. We hypothesized that $\mathrm{N}$ availability and distinct forms of $\mathrm{N}$ would not alter percent germination or germination rate of these species when provided adequate moisture (Hypothesis I). Additionally, we hypothesized that early seedling growth of the invasive annuals, but not the perennials, would be greater when provided $\mathrm{NO}_{3}{ }^{-}$ rather than $\mathrm{NH}_{4}{ }^{+}$(Hypothesis II).

\section{Materials and Methods}

\section{Plant Species}

We collected cheatgrass (CG) and medusahead (MH) seed from populations located on southwest facing slopes ( $1,450 \mathrm{~m}$ elev.) in Cache County, Ut. (41 ${ }^{\circ}$ $46^{\prime} 07^{\prime \prime} \mathrm{N}, 111^{\circ} 47^{\prime} 11^{\prime \prime} \mathrm{W}$ for cheatgrass and $41^{\circ} 32^{\prime} 18^{\prime \prime} \mathrm{N}, 111^{\circ} 48^{\prime \prime} 00^{\prime \prime} \mathrm{W}$ for medusahead). We refer to seed collected in summer 1997 as CG1 and MH1 and seed collected in summer 2000 as CG2 and $\mathrm{MH} 2$. We obtained seed for the following 6 perennial grasses: 'Goldar' bluebunch wheatgrass (Pseudoroegneria spicata [Pursh] A. Löve), 'CD II' crested wheatgrass (Agropyron cristatum (L.) Gaertner x A. desertorum (Fisch. ex Link) Schultes), Sand Hollow (Jones et al. 1998) and Seaman's Gulch big squirreltail (Elymus multisetus [J.G. Smith] M.E. Jones), and Little Camas and Little Wood bottlebrush squirreltail (E. elymoides [Raf.] Swezey ssp. brevifolius and E. elymoides ssp. elymoides, respectively) from the USDA-ARS Forage and Range Research Laboratory in Logan, Ut. Seeds of bluebunch wheatgrass, Sand Hollow big squirreltail, crested wheatgrass, and the invasive annual grasses collected in 2000 (CG1 and MH2) were used in the soil germination experiment. All 10 grasses were used in the hydroponic experiment. Seeds of cheatgrass, medusahead, and squirreltail were de-awned prior to the experiments.

\section{Soil Germination Experiment}

The effects of mineral $\mathrm{N}$ form and availability on seed germination were evaluated in soil excavated from Dugway Proving Grounds ( $\left.40^{\circ} 14^{\prime} 23^{\prime \prime} \mathrm{N}, 112^{\circ} 50^{\prime} 47^{\prime \prime} \mathrm{W}\right)$ in Tooele County, Ut. to a maximum depth of $60 \mathrm{~cm}$. The top $2 \mathrm{~cm}$ of soil and litter were discarded to remove existing seeds on the soil surface. The soil was classified as coarse-loamy, mixed, calcareous, superactive, mesic Xeric Torriorhent and is a member of the Medburn Series (Trickler et al. 2000). The $\mathrm{pH}_{\mathrm{H} 2 \mathrm{O}}$ of the soil was 8.2 , and cation exchange capacity (CEC) was 7-cmol kg-1 soil. Total soil carbon (C) $\left(13 \mathrm{~g} \mathrm{~kg}^{-1}\right)$ and total soil $\mathrm{N}(1.0 \mathrm{~g}$ $\mathrm{kg}-1)$ were determined by direct combustion with a LECO CHN-1000 Autoanalyzer (LECO Corp., St. Joseph, Mich. $)^{1}$. The gravimetric water contents at field capacity $(-0.033 \mathrm{MPa})$ and permanent wilting point $(-1.50 \mathrm{MPa})$ were 6.9 and $3.6 \%$, respectively. The soil was passed through a 6-mm sieve to remove rocks and organic debris and then thoroughly mixed. Soil was placed in 30-liter plastic containers assigned to the following 5 soil treatments: 1 ) control = nothing added to soil, 2) straw = barley straw (1 $\mathrm{mg} \mathrm{kg}^{-1}$ soil) ground to pass a $1-\mathrm{mm}$ screen, 3) $\mathrm{NH}_{4}^{+}=10 \mathrm{mg} \mathrm{N} \mathrm{kg}^{-1}$ soil added as $\left.\left(\mathrm{NH}_{4}\right)_{2} \mathrm{SO}_{4}, 4\right) \mathrm{NH}_{4}^{+}+\mathrm{I}$ (nitrification inhibitor) $=10 \mathrm{mg} \mathrm{N} \mathrm{kg}^{-1}$ soil added as $\left(\mathrm{NH}_{4}\right)_{2} \mathrm{SO}_{4}+37 \mathrm{ml}$ nitrapyrin $(29 \%$ a.i., 2-chloro-6-(trichloromethyl) pyridine), and 5) $\mathrm{NO}_{3}^{-}=10 \mathrm{mg} \mathrm{N} \mathrm{kg}^{-1}$ soil added as $\mathrm{Ca}\left(\mathrm{NO}_{3}\right)_{2}$. Nitrapyrin inhibits the first nitrification step of bacterial $\mathrm{NH}_{4}{ }^{+}$oxidation and stabilizes $\mathrm{NH}_{4}{ }^{+}$in soils for about 60 days. The straw treat-

\footnotetext{
${ }^{1}$ Mention of a trade name does not imply an endorsement or recommendation by USDA over similar products or companies not mentioned.
}

ment was designed to decrease overall mineral $\mathrm{N}$ availability by promoting microbial immobilization of mineral $\mathrm{N}$. The C:N ratio of the straw we used was 98 as measured with a LECO CHN-2000 Autoanalyzer (LECO Corp., St. Joseph, Mich.). Preliminary experiments indicated nearly all (>95\%) extractable soil mineral $\mathrm{N}$ was immobilized by the straw treatment within 5 days when at field capacity $(6.9 \%)$. Thus, the straw treatment was watered to field capacity 5 days prior to the experiment, and the other 4 treatments were applied 1 day prior to the experiment with sufficient water to reach field capacity. Preliminary experiments indicated that treatment solutions were evenly distributed throughout soils within 24 hours.

The soil germination experiment was a completely randomized design with 5 treatments, 8 grasses, and 4 replications. The entire experiment was repeated 3 times on different dates. The 5 soil treatments were produced within plastic germination boxes $(11 \mathrm{~cm} \mathrm{x} 11 \mathrm{~cm} \mathrm{x} 4 \mathrm{~cm})$. To each box we added $250 \mathrm{~g}$ of soil (at field capacity) by shaking soil through 2 wiremesh screens $(2-\mathrm{mm})$, placed 100 grass seeds spaced $1-\mathrm{cm}$ apart on the soil surface, and added $50 \mathrm{~g}$ of soil to cover seeds $(\sim 3 \mathrm{~mm})$. Soil in each box was then lightly compressed with a wood block, and the soil surface dampened with de-ionized water to maintain soil dampness. Germination boxes were sealed with a lid and placed in a dark, temperature-controlled incubator held at $20^{\circ} \mathrm{C}$ for 20 days. Each box was evaluated daily and systematically relocated within the incubator. Germinated seeds (plumule emerged from soil surface) were removed with tweezers to minimize soil disturbances and resprayed with de-ionized to maintain soil dampness. Additionally, germination of each grass was evaluated by placing 100 seeds on blue blotter paper (Anchor Paper, St. Paul, Minn.) within seed boxes. Blotter paper germination was evaluated only once with each species replicated 4 times. Germination was evaluated for 20 days under the same incubator conditions as the soil experiment. De-ionized water was added when necessary to maintain visible wetness between the seeds and the blotter paper.

Soils of each treatment were analyzed at Day 10 for mineral $\mathrm{N}$ according to the methods described by Hart et al. (1994). Soils for $\mathrm{N}$ analysis were taken from an additional 8 replications of each treatment that were prepared with the first run of the experiment. These 8 additional treatment replications were seeded with crested 
wheatgrass to provide an accurate estimate of soil $\mathrm{NO}_{3}{ }^{-}$and $\mathrm{NH}_{4}{ }^{+}$at the midpoint of the experiment. A $10-\mathrm{g}$ soil sample was taken from each seed box, homogenized, and extracted with $2 \mathrm{M} \mathrm{KCl}$ within 4 hours. Extracts were filtered through filter paper pre-leached with $2 \mathrm{M} \mathrm{KCl}$ and frozen until analyzed. Concentrations of $\mathrm{NO}_{2}^{-}+\mathrm{NO}_{3}^{-}$and $\mathrm{NH}_{4}{ }^{+}$were analyzed colorimetrically with a flow injection autoanalyzer (Lachat Instruments, Milwaukee, Wis.) using standard procedures (Lachat 1989, 1990).

\section{Hydroponic Experiment}

The influence of distinct forms of mineral $\mathrm{N}$ on germination and subsequent seedling growth of the 2 invasive annual grasses and the 6 perennial grasses were evaluated in a hydroponic experiment. Because both $\mathrm{NO}_{3}{ }^{-}$and $\mathrm{NH}_{4}{ }^{+}$forms are readily soluble in water, a hydroponic system was used to allow a direct comparison of mineral $\mathrm{N}$ forms independent of differences in nutrient mobility that could impact $\mathrm{N}$ uptake. Four aerated 15-liter tanks were filled with water and $\mathrm{N}$-free modified 10\% Hoagland's solution (trace elements and $\mathrm{Fe}$ at full strength). Holes in the lid of each tank accommodated the placement of $20-\mathrm{ml}$ disposable beakers that rested at the surface of the hydroponic solution. These small beakers had a 16$\mathrm{mm}$ diameter hole in the bottom that was covered by a large-mesh screen and contained $2 \mathrm{ml}$ of agar $(0.75 \%)$. In each beaker, 6 seeds of 1 of the grasses were placed on the agar surface with the seed crease facing down and the embryo towards the center. The $\mathrm{N}$-free modified $10 \%$ Hoagland's solution was used to prepare nutrient agar with $4 \mathrm{~N}$-form treatments. Treatments were control $=$ no $\mathrm{N}$ added, $\mathrm{NH}_{4}{ }^{+}(1 \mathrm{mM}), \mathrm{NO}_{3}^{-}(1 \mathrm{mM})$, and $\mathrm{NH}_{4} \mathrm{NO}_{3}(0.5 \mathrm{mM}=1 \mathrm{mM} \mathrm{N})$. The hydroponic tanks were kept indoors at room temperature. Photosynthetically active radiation $\left(350 \mathrm{mmol} \mathrm{m} \mathrm{mec}^{-1}\right)$ was provided to plants for 16 hours per day to sustain vegetative growth. Radiation was provided with a combination lamp enclosure that had one $400 \mathrm{~W}$ metal halide lamp and one $600-\mathrm{W}$ high-pressure sodium lamp (Sunlight Supply Inc., Vancouver, Wash.). The lamp continually moved lengthwise along a motorized light track to enhance uniformity of light distribution. The hydroponic experiment was a completely randomized design with 4 treatments, 10 grasses, and 3 replicates assigned to different hydroponic tanks.

All solutions were monitored and maintained at pH 6.1 either manually or with an automated $\mathrm{pH}$ controller in the case of the $\mathrm{NH}_{4}{ }^{+}-\mathrm{N}$ treatment. Nitrogen levels were monitored, and solutions were replaced periodically to maintain $\mathrm{N}$ concentrations within $20 \%$ of the initial levels. Germinated seeds were counted at Day 10, and maximum root and shoot length were measured at Day 10 and 21. We anticipated that rapid germination would equate to greater shoot and root growth during the experiment. All plants were harvested and oven dried $\left(60^{\circ}\right.$ C) to constant weight to determine root and shoot dry mass on Day 21.

\section{Statistical Procedures}

All statistical analyses were performed with $\alpha=0.05$. The effects of soil $\mathrm{N}$ treatment on germination of the 8 grasses and blotter paper germination were analyzed with PROC GLM (SAS 1999) and tested for significance of grass, $\mathrm{N}$ treatment, and the interactions. Treatment differences in the concentration of mineral soil $\mathrm{N}$ were analyzed with one-way ANOVA. All means were compared with Tukey's (HSD) test. Effects of the hydroponic treatments on germination and seedling growth of the 5 species were analyzed with a mixed ANOVA model for grass, soil treatment, and the interactions (Littell et al. 1996).

\section{Results}

\section{Soil Germination Experiment}

Soil treatments were effective at manipulating mineral-N form and availability in the germination boxes (Fig. 1). Soil $\mathrm{NO}_{3}{ }^{-}$ concentration was 3.5 times greater in the $\mathrm{NO}_{3}{ }^{-}$treatment than any of the other treatments during the middle of the soil germination experiment. Soil concentrations of $\mathrm{NH}_{4}^{+}$in the $\mathrm{NH}_{4}^{+}$and $\mathrm{NH}_{4}^{+}+$I treatments were about 5 times greater than the control, straw, or $\mathrm{NO}_{3}{ }^{-}$treatment. Consequently, total mineral- $\mathrm{N}$ concentration $\left(\mathrm{NO}_{3}{ }^{-}+\mathrm{NH}_{4}{ }^{+}\right)$of the $3 \mathrm{~N}$ treatments did not differ more than $5 \%$, and their average was 2.6 and 75 times greater than the control and straw treatments, respectively.

Cumulative germination percent differed significantly among the grasses as early as 3 days (Fig. 2), but neither soil treatment nor soil treatment $x$ grass interactions significantly affected germination. Medusahead reached maximum percentage germination at Day 3, whereas the other grasses generally did not reach this point until Day 5. Bluebunch wheatgrass and Sand Hollow big squirreltail did not reach maximum percentage germination until Day 11, and cheatgrass seeds continued to germinate until Day 17. Cumulative percentage germination for medusahead and Little Camas bottlebrush squirreltail at

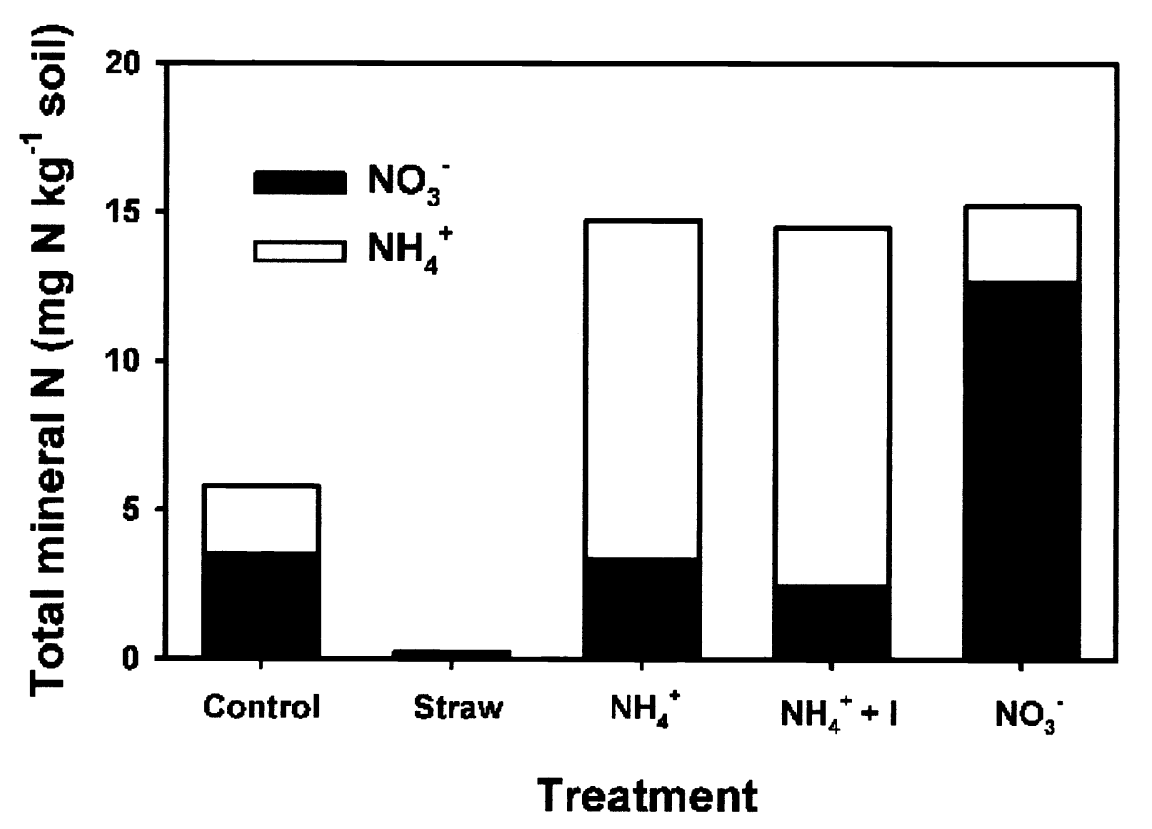

Fig. 1. Mean $(\mathrm{n}=8)$ soil $\mathrm{NO}_{3}{ }^{-}$and $\mathrm{NH}_{4}{ }^{+}$concentrations at Day 10 for 5 treatments evaluating the effects of mineral $N$ forms and $N$ availability on the germination of 2 invasive annual grasses and 6 perennial grasses. 


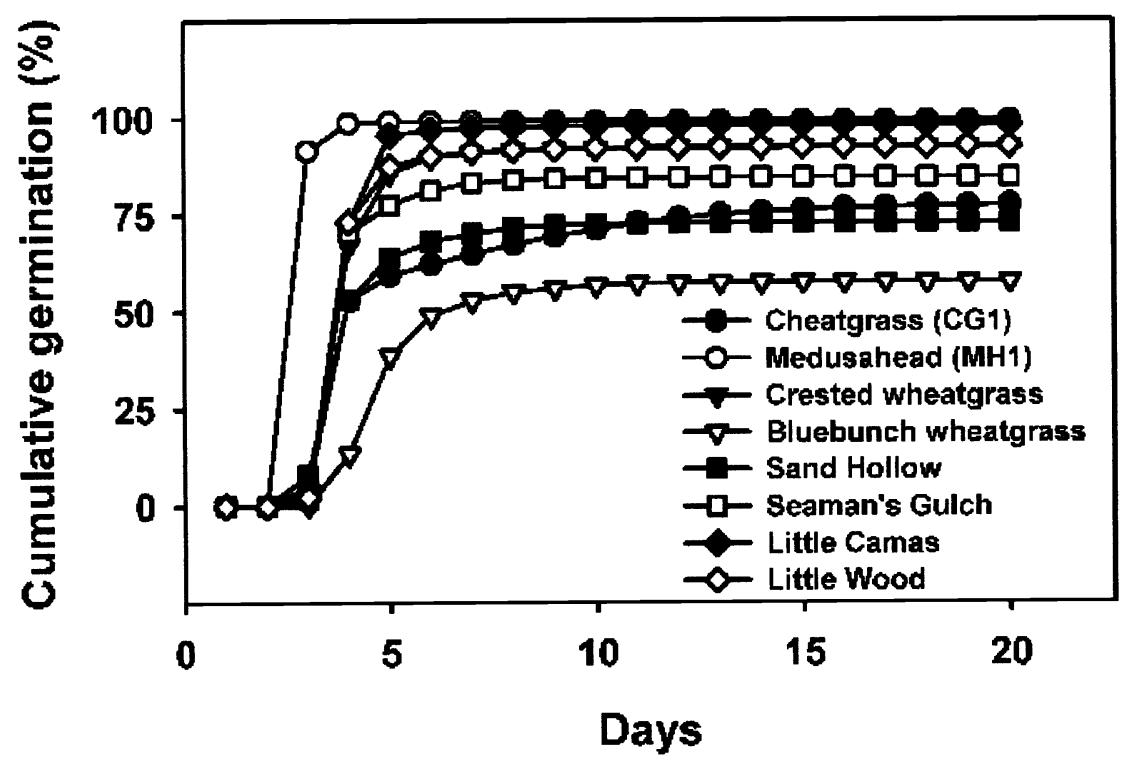

Fig. 2. Mean $(n=4)$ cumulative germination percentage of 2 invasive annual grasses and 6 perennial grasses exposed to 5 soil treatments that differed in mineral $\mathbf{N}$ forms and $\mathbf{N}$ availability for 20 days.

Day 20 was 99 and $98 \%$, respectively, and was significantly greater than all other grasses. Crested wheatgrass and Little Wood bottlebrush squirreltail equally had the second highest cumulative percent germination of $92 \%$, which significantly exceeded the remaining 4 grasses at Day 20. Bluebunch wheatgrass had the lowest cumulative germination percent $(50 \%)$ at Day 20. Values for maximum cumulative germination in soil were comparable to values obtained on blotter paper without $\mathrm{N}$ additions (data not shown).

\section{Hydroponic Experiment}

Nitrogen treatment, grass, and treatment $\mathrm{x}$ grass interactions were significant for all seedling variables with the exception of treatment and the treatment $x$ grass interaction for percentage germination. Germination of MH1 was almost $24 \%$ greater than $\mathrm{MH} 2$ (Table 1). Germination percentage was higher in the hydroponic system than in soil for CG1, bluebunch wheatgrass, and Sand Hollow big squirreltail.

Absolute shoot growth values of annual and perennial grasses were generally greater in the $\mathrm{NO}_{3}{ }^{-}$treatment than in the $\mathrm{NH}_{4}{ }^{+}$treatment (Fig. 3), but significant differences were observed only for 5 of the native perennial grasses. Bluebunch wheatgrass and Seaman's Gulch and Little Wood squirreltails had significantly greater shoot dry mass in the $\mathrm{NO}_{3}{ }^{-}$treatment compared to the $\mathrm{NH}_{4}{ }^{+}$treatment. Bluebunch wheatgrass was the only grass with significantly greater shoot length at Day 10 in the $\mathrm{NO}_{3}{ }^{-}$treatment compared to the $\mathrm{NH}_{4}^{+}$treatment. However, at Day 21 , the 4 squirreltail populations were the only grasses to have significantly greater shoot length in the $\mathrm{NO}_{3}^{-}$treatment than the $\mathrm{NH}_{4}^{+}$treatment. Cheatgrass was the only grass to have significantly greater shoot dry mass (CG1 and CG2) and shoot length (CG2) at Day 21 when grown in the $\mathrm{NH}_{4} \mathrm{NO}_{3}$ treatment compared to the $\mathrm{NO}_{3}{ }^{-}$ treatment. Three of the squirreltails (Sand Hollow, Seaman's Gulch, and Little Camas) and medusahead (MH1) had significantly longer shoots than cheatgrass (CG1 and CG2) at Days 10 and 21 in the control treatment. Crested wheatgrass shoot lengths (at Days 10 and 21) in the control treatment were significantly less than 3 squirreltails (Sand Hollow, Seaman's Gulch, and Little Camas) at Day 10 and significantly less than all squirrelails and medusahead (MH1) at Day 21.

Root dry mass of $\mathrm{MH} 1$ in the control was significantly lower than all $3 \mathrm{~N}$ treatments (Fig. 4). The magnitude of difference in absolute root dry mass between the control and the $\mathrm{NH}_{4} \mathrm{NO}_{3}$ treatment was consistently lower for bluebunch wheatgrass and Sand Hollow and Seaman's Gulch big squirreltails compared to the invasive annual grasses and crested wheatgrass. For example, absolute root dry mass was 2- to 4-fold greater in the $\mathrm{NH}_{4} \mathrm{NO}_{3}$ treatment than in the control for cheatgrass (CG1 and CG2) and medusahead (MH2), while a response of this magnitude for perennial grasses was observed only in crested wheatgrass. Root dry mass was significantly greater in the $\mathrm{NO}_{3}{ }^{-}$treatment than in the $\mathrm{NH}_{4}{ }^{+}$treatment for crested wheatgrass only.

Root length was generally greater in the $\mathrm{N}$-free control treatment than in the $3 \mathrm{~N}$ treatments for most grasses, and this effect was more pronounced at Day 21 than Day 10 (Fig. 4). Medusahead (MH1 and MH2) root length at Days 10 and 21 in the control treatment exceeded $(\mathrm{P}<0.05)$ that of perennial grasses with the exception of crested wheatgrass. Root lengths for both medusahead populations and 1 cheatgrass population (CG1) were significantly greater than all of the other grasses at Day 10 within the $3 \mathrm{~N}$ treatments. Roots of perennial grasses except bluebunch wheatgrass, and 1 medusahead population (MH1), were longer in the $\mathrm{NO}_{3}^{-}$treatment than in the $\mathrm{NH}_{4} \mathrm{NO}_{3}{ }^{-}$treatment at Day 10 $(\mathrm{P}<0.05)$. However, cheatgrass $(\mathrm{CG} 2)$ was the only grass to have significantly longer roots in the $\mathrm{NO}_{3}^{-}$treatment than the $\mathrm{NH}_{4}^{-}$treatment by Day 21 .

Shoot:root ratios were 2 to 2.5 fold greater in the $3 \mathrm{~N}$ treatments than the control for all grasses (Fig. 5). Cheatgrass (CG1 and CG2) had significantly lower shoot:root ratios than perennial grasses in the control. Similarly, the shoot:root ratio of medusahead was significantly less than Sand Hollow and Seaman's Gulch big squirreltails in the control treatment. Crested wheatgrass had a shoot:root ratio that was intermediate and similar to the other perennial grasses and the invasive annual grasses. Grasses other than cheatgrass, crested wheatgrass, and Little Camas bottlebrush squirreltail had greater shoot:root ratios in the $\mathrm{NO}_{3}{ }^{-}$than the $\mathrm{NH}_{4}{ }^{+}$treatment $(\mathrm{P}<0.05)$. In addition, absolute shoot:root ratios in the $\mathrm{NO}_{3}{ }^{-}$

Table 1. Mean ( $\pm 1 \mathrm{SE} ; n=3$ ) percentage germination based on appearance of root and shoot organs at 10 days after planting 6 seeds on agar contained in a culture assembly suspended over aerated nutrient solutions. Values followed by different letters indicate significant differences at $\mathbf{P}<0.05$.

\begin{tabular}{ll}
\hline \hline Grass & Germination \\
\hline & $----(\%)-----$ \\
Cheatgrass (CG1) & $84.7 \pm 4.3 \mathrm{ab}$ \\
Cheatgrass (CG2) & $94.4 \pm 2.4 \mathrm{a}$ \\
Medusahead (MH1) & $98.6 \pm 1.4 \mathrm{a}$ \\
Medusahead (MH2) & $75.0 \pm 4.6 \mathrm{~b}$ \\
Crested wheatgrass & $90.3 \pm 3.2 \mathrm{ab}$ \\
Bluebunch wheatgrass & $91.7 \pm 3.2 \mathrm{a}$ \\
Sand Hollow & $86.1 \pm 4.0 \mathrm{ab}$ \\
Seaman's Gulch & $84.7 \pm 4.8 \mathrm{ab}$ \\
Little Camas & $98.6 \pm 1.4 \mathrm{a}$ \\
Little Wood & $94.4 \pm 2.4 \mathrm{a}$ \\
\hline
\end{tabular}




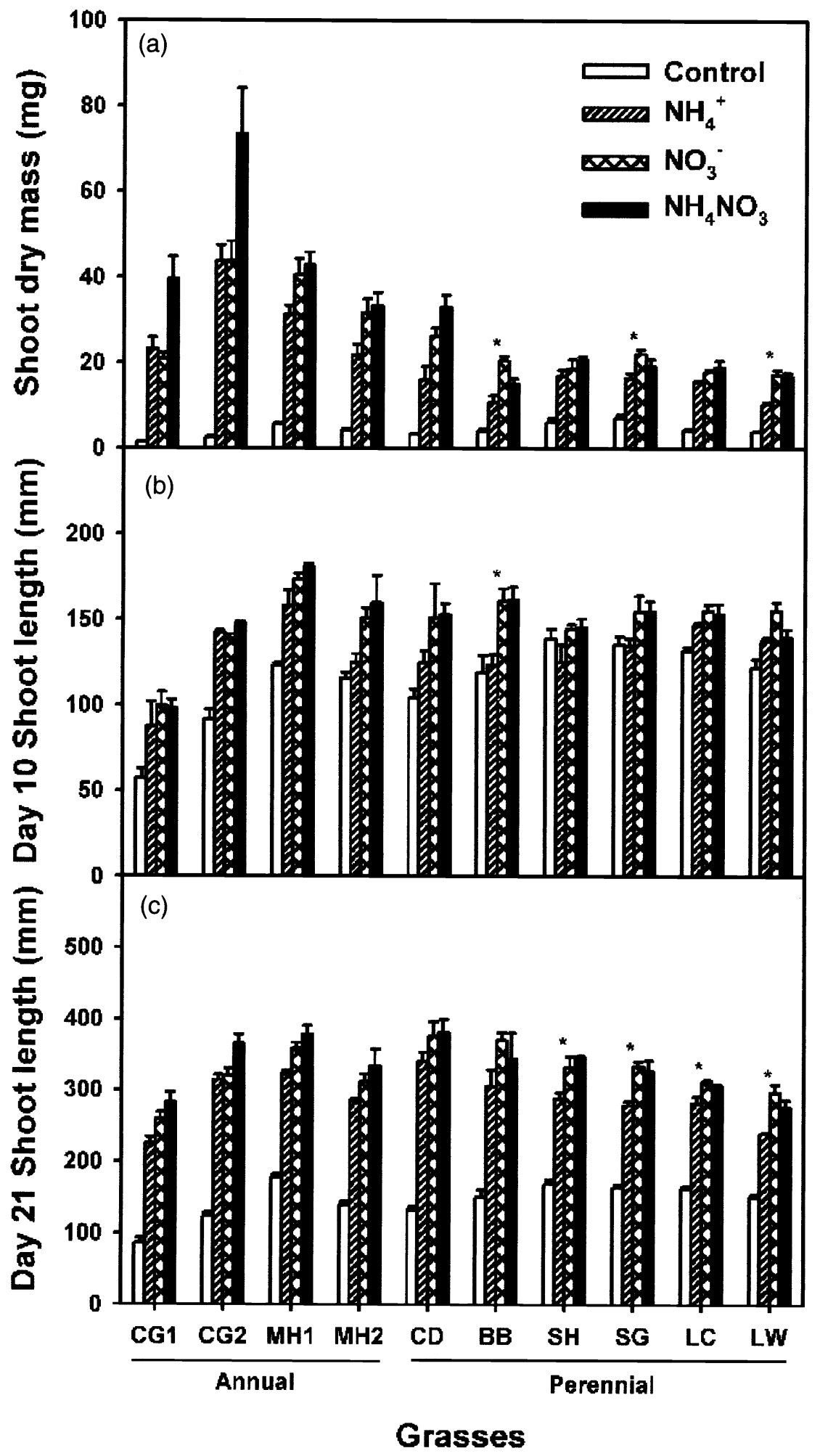

Fig. 3. Mean ( $\pm 1 \mathrm{SE} ; \mathbf{n}=3$ ) shoot dry mass (a), shoot length at 10 days after planting (b), and shoot length at 21 days after planting (c) for populations of cheatgrass (CG1 and CG2), medusahead (MH1 and MH2), crested wheatgrass (CD), bluebunch wheatgrass (BB), and 4 squirreltails: Sandhollow (SH), Seaman's Gulch (SG), Little Camas (LC), and Little Wood (LW). Plants were grown in a hydroponic system to evaluate growth responses to mineral $\mathrm{N}$ forms and $\mathrm{N}$ availability. Asterisks above bars denote significant $(\mathrm{P}<0.05)$ differences between the $\mathrm{NH}_{4}^{+}$and $\mathrm{NO}_{3}^{-}$treatments. treatment exceeded those in the $\mathrm{NH}_{4} \mathrm{NO}_{3}$ treatment for all grasses except cheatgrass and Little Camas bottlebrush squirreltail.

\section{Discussion}

The results of our germination experiments provide strong evidence that differences in $\mathrm{N}$ availability and forms of mineral $\mathrm{N}$ do not alter cumulative germination percentage of the populations of grasses we evaluated (Hypothesis I). Our hydroponic experiment demonstrated that seedling growth of annual and perennial grasses were generally greater when provided $\mathrm{NO}_{3}^{-}$rather than $\mathrm{NH}_{4}^{+}$. However, the perennial grasses generally showed a greater response to $\mathrm{NO}_{3}{ }^{-}$relative to $\mathrm{NH}_{4}{ }^{+}$ than the invasive annual grasses, which is contrary to Hypothesis II.

\section{Soil Germination Experiment}

Results from our germination experiment are similar to those of Goebel et al. (1988), who found medusahead germinated in one-third the time of bluebunch wheatgrass. Lower and slower germination percentage in bluebunch wheatgrass compared to the other grasses is likely one of the major factors that limit its ability to compete successfully with invasive annual grasses (Harris 1967). In contrast, more rapid and higher maximum germination percentage, as observed in crested wheatgrass and Little Camas and Little Wood squirreltails, may enable seedling emergence of these perennial grasses to coincide with the emergence of invasive annual grasses and to successfully compete with them (Forcella et al. 2000). Such advantages gained as seedlings are often retained as mature plants (Silverton and Dickie 1980, TeKrony and Egli 1991).

The results of our soil germination experiment agreed with those of other studies, demonstrating modifications in soil $\mathrm{N}$ do not alter seed germination of many grass and broad leaf weed species (Andrews et al. 1991, Riba et al. 2002). The lack of seed germination control by distinct forms of mineral $\mathrm{N}$ in our experiment may be associated with low levels of seed dormancy in the seeds evaluated. Varying levels of seed dormancy have been documented in medusahead and cheatgrass populations from disparate locations throughout the Great Basin, with populations from the relatively more arid regions generally having higher acquired dormancy (McKell et al. 1962, Meyer and Allen 1999). Non-dormant seeds of cheatgrass are known to germinate rapidly and completely regardless of genotype or envi- 


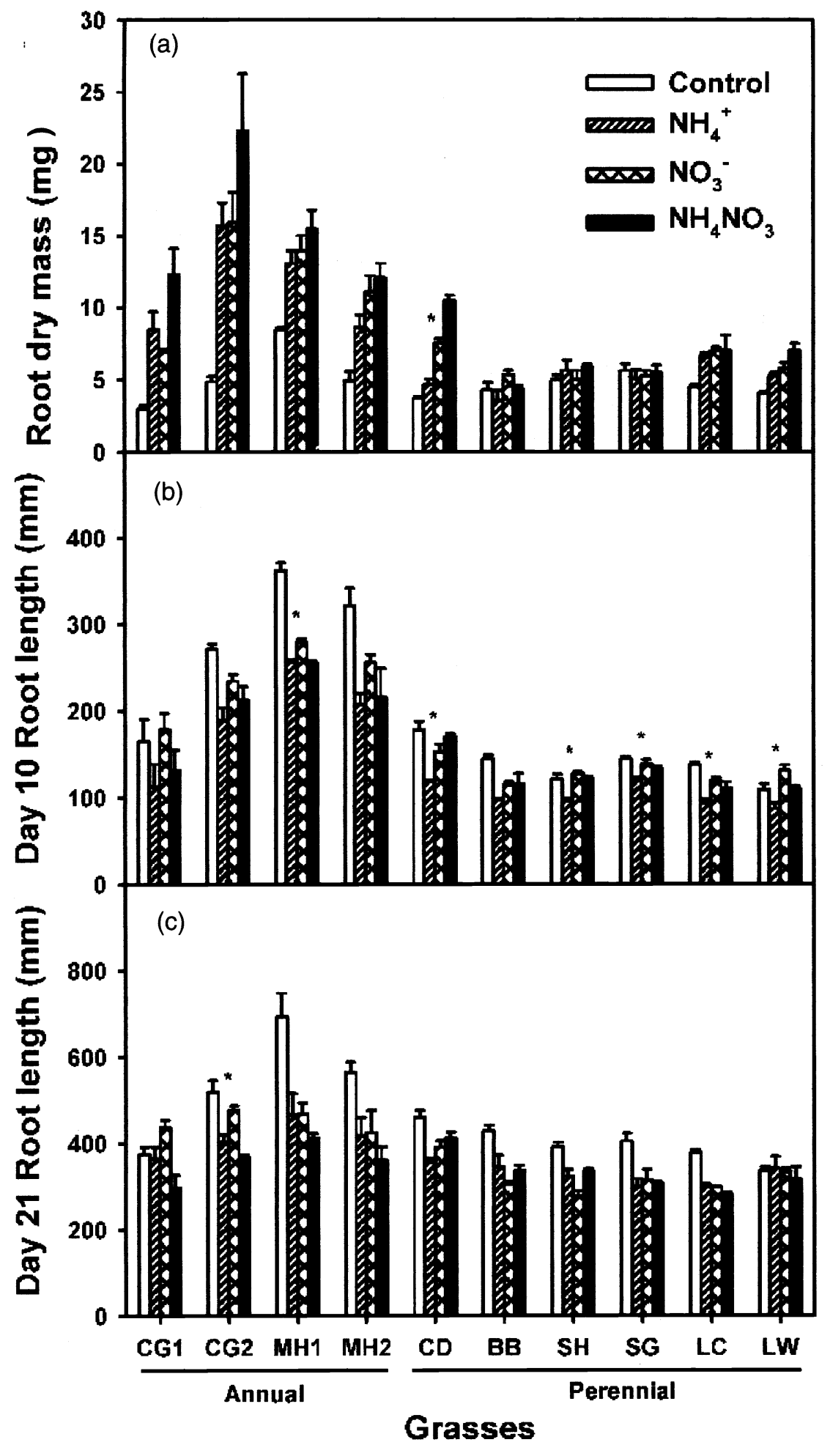

Fig. 4. Mean ( $\pm 1 \mathrm{SE} ; n=3)$ root dry mass $(a)$, root length at 10 days after planting (b), and root length at 21 days after planting (c) for populations of cheatgrass (CG1 and CG2), medusahead (MH1 and MH2), crested wheatgrass (CD), bluebunch wheatgrass (BB), and 4 squirreltails: Sandhollow (SH), Seaman's Gulch (SG), Little Camas (LC), and Little Wood (LW). Plants were grown in a hydroponic system to evaluate growth responses to mineral $\mathbf{N}$ forms and $\mathrm{N}$ availability. Asterisks above bars denote significant $(\mathrm{P}<0.05)$ differences between the $\mathrm{NH}_{4}^{+}$and $\mathrm{NO}_{3}^{-}$treatments. ronmental factors (Allen and Meyer 2002). However, if seed water contents are not favorable for germination in the autumn following seed production, seeds of cheatgrass and medusahead may acquire dormancy (Hulbert 1955, Sharp et al. 1957, Young et al. 1969) and require specific environmental or chemical stimuli like $\mathrm{NO}_{3}{ }^{-}$to break dormancy (Evans and Young 1975, Hilton and Thomas 1986, Pons 1989, McIntyre et al. 1996).

\section{Hydroponic Experiment}

Initial root lengths at Day 10 and overall seedling shoot growth of perennial grasses responded more positively to $\mathrm{NO}_{3}{ }^{-}$relative to $\mathrm{NH}_{4}{ }^{+}$than did invasive annual grasses. These results provide the principal justification for rejecting Hypothesis II. However, by Day 21, root lengths were similar in the $\mathrm{NO}_{3}{ }^{-}$and $\mathrm{NH}_{4}{ }^{+}$treatments for all grasses except cheatgrass (CG2), suggesting distinct mineral forms produced merely a transient effect on root lengths. In contrast, the number of perennial grasses with significantly greater shoot lengths in the $\mathrm{NO}_{3}{ }^{-}$treatment than the $\mathrm{NH}_{4}{ }^{+}$treatment increased between Day 10 and 21. Similarly, Glinski et al. (1990) found that root growth and root:shoot ratios of creeping bentgrass (Agrostis palustris Hudson) were higher when $\mathrm{NO}_{3}{ }^{-}$was the predominant form of mineral N. These responses may be associated with different carbon costs for $\mathrm{N}$ uptake and assimilation in perennial compared to invasive annual grasses (e.g., Anandacoomaraswamy et al. 2002), even though the carbon costs of assimilating $\mathrm{NO}_{3}{ }^{-}$are generally greater than $\mathrm{NH}_{4}{ }^{+}$ (Clarkson 1985). It is also possible that $\mathrm{NH}_{4}+$ may have inhibited radicle elongation (Westwood and Foy 1999) and contributed to less root growth in the $\mathrm{NH}_{4}{ }^{+}$ than the $\mathrm{NO}_{3}{ }^{-}$treatment. The ecological significance of perennial grasses being more responsive than annual grasses to the $\mathrm{NO}_{3}^{-}$vs. $\mathrm{NH}_{4}{ }^{+}$comparison is unknown, but further identification of the underlying mechanisms responsible for these responses may reveal critical insights into competitive interactions between these 2 groups of grasses.

Early seedling root and shoot growth must be tailored to take advantage of soil $\mathrm{N}$ that rapidly becomes available to plants following nutrient flushes associated with precipitation and soil disturbance events (Chapin 1980, Fisher et al. 1987, Burke 1989). Our results suggest invasive annual grasses may be more capable to take advantage of ephemeral pulses of $\mathrm{N}$ in rangeland soils than perennial grasses. 


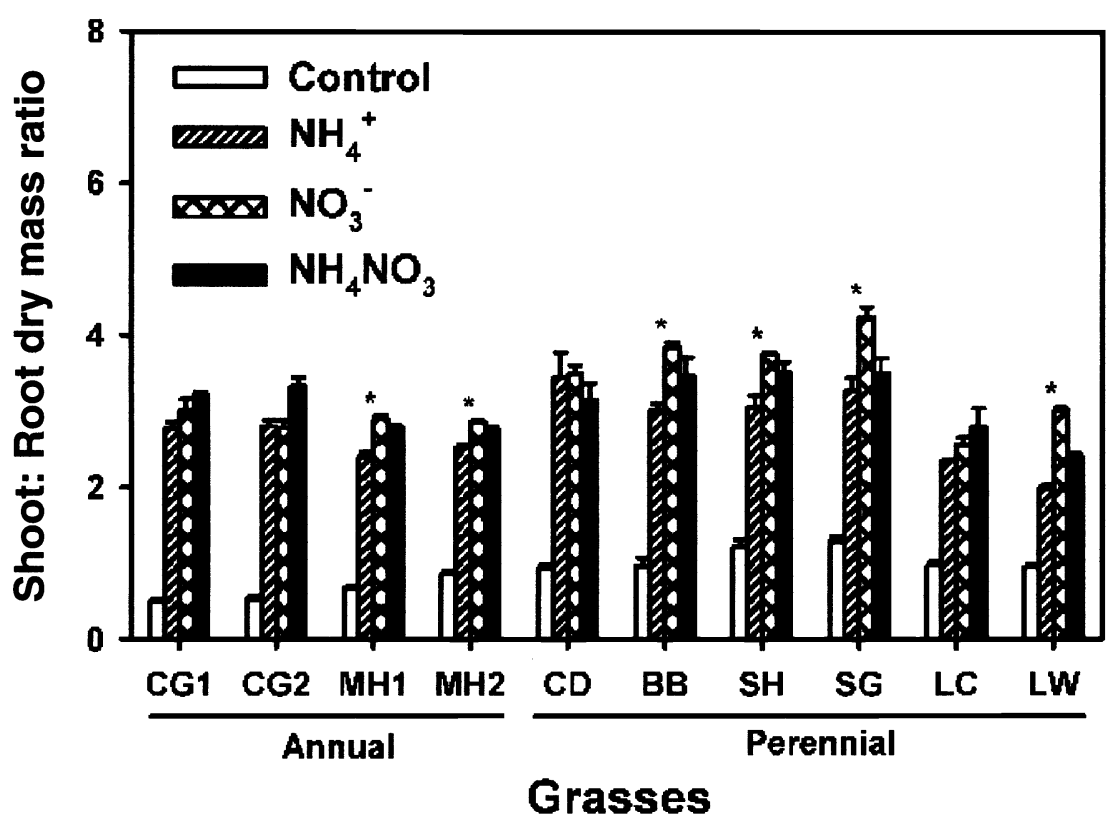

Fig. 5. Mean ( \pm 1 SE; $n=3$ ) shoot:root dry mass for populations of cheatgrass (CG1 and CG2), medusahead (MH1 and MH2), crested wheatgrass (CD), bluebunch wheatgrass (BB), and 4 squirreltails: Sandhollow (SH), Seaman's Gulch (SG), Little Camas (LC), and Little Wood (LW). Plants were grown in a hydroponic system to evaluate growth responses to mineral $\mathrm{N}$ forms and $\mathrm{N}$ availability. Asterisks above bars denote significant $(\mathrm{P}<0.05)$ differences between the $\mathrm{NH}_{4}{ }^{+}$and $\mathrm{NO}_{3}{ }^{-}$treatments.

Root and shoot growth of medusahead seedlings exceeded all grasses except crested wheatgrass regardless of treatment (Hironaka 1961, Harris 1977). Our experiment showed medusahead and cheatgrass generally had greater root dry mass and more rapid development of root length (at Day 10) than the other grasses except crested wheatgrass. Similarly, Harris and Wilson (1970) found roots of crested wheatgrass grew faster than bluebunch wheatgrass and almost as fast as cheatgrass and medusahead roots. Our observation that crested wheatgrass root responses were intermediate to the annual and native perennial grasses confirm previous reports that crested wheatgrass has greater earlyspring root growth and root proliferation in fertilized soil microsites (Eissenstat and Caldwell 1988, Caldwell et al. 1991) and earlier seedling emergence (Pyke 1990) than the native perennial, bluebunch wheatgrass. Collectively, these data explain mechanisms whereby faster-growing annual grasses (Arredondo et al. 1998) with high $\mathrm{NO}_{3}{ }^{-}$uptake and greater $\mathrm{N}$ productivity (i.e., biomass produced per unit of N) (Poorter et al. 1990, Garnier and Vancaeyzeele 1994) reduce the success of seeded perennial grasses on semiarid rangelands (Hironaka 1961). ability to exploit nutrients and rapidly produce more root (Harris 1967) and shoot mass than perennial grasses (Svejcar 1990). Our observation of lower percentage reduction in seedling growth in low compared to high soil $\mathrm{N}$ availability in the perennial grasses than the invasive annual grasses suggests that reducing mineral $\mathrm{N}$ may improve the relative establishment of perennial grasses by impeding growth of invasive annuals (Borman et al. 1991).

\section{Literature Cited}

Allen, P.S. and S.E. Meyer. 2002. Ecology and ecological genetics of seed dormancy in downy brome. Weed Sci. 50:241-247.

Anandacoomaraswamy A., W.A.J.M. De Costa, P.L.K. Tennakoon, and A. Van der Werf. 2002. The physiological basis of increased biomass partitioning to roots upon nitrogen deprivation in young clonal tea (Camellia sinensis (L.) O. Kuntz). Plant Soil 238:1-9.

Andrews, M., W.R. Scott, and B.A. McKenzie. 1991. Nitrate effects on pre-emergence growth and emergence percentage of wheat (Triticum aestivum $\mathrm{L}$.) from different sowing depths. J. Exp. Bot. 42:1449-1454.

Arredondo, J.T., T.A. Jones, and D.A. Johnson. 1998. Seedling growth of Intermountain perennial and weedy annual grasses. J. Range Manage. 51:584-589.

Borman, M.M., W.C. Krueger, and D.E. Johnson. 1991. Effects of established perennial grasses on yields of associated annual weeds. J. Range Manage. 44:318-322.

Burke, I.C. 1989. Control of nitrogen mineralization in a sagebrush steppe landscape. Ecol. 70:1115-1126.

Burke, M.M.W. and J.P. Grime. 1996. An experimental study of plant community invasibility. Ecol. 77:776-790.

Caldwell, M.M., J.H. Manwaring, and S.L. Durham. 1991. The microscale distribution of neighbouring plant roots in fertile soil microsites. Funct. Ecol. 5:765-772.

Chapin, F.S., III. 1980. The mineral nutrition of wild plants. Annu. Rev. Ecol. Syst. 11:233-260.

Clarkson, D.T. 1985. Factors affecting mineral nutrient acquisition by plants. Annu. Rev. Plant Physiol. 36:77-115.

Davis, M.A., J.P. Grime, and K. Thompson. 2000. Fluctuating resources in plant communities: a general theory of invasibility. J. Ecol. 88:528-534.

Eissenstat, D.M. and M.M. Caldwell. 1988. Seasonal timing of root growth in favorable microsites. Ecol. 69: 870-873.

Evans, R.A. and J.A. Young. 1975. Enhancing germination of dormant seeds of downy brome. Weed Sci. 23:354-357. 
Fisher, F.M, L.W. Parker, J.P. Anderson, and W.G. Whitford. 1987. Nitrogen mineralization in a desert soil: interacting effects of soil moisture and nitrogen fertilizer. Soil Sci. Soc. Amer. J. 51:1033-1041.

Forcella, F., R.L. Benech Arnold, R. Sanchez, and C.M. Ghersa. 2000. Modelling seedling emergence. Field Crops Res. 67:123-139.

Glinski, D.S., H.A. Mills, K.J., Karnok, and R.N. Carrow. 1990. Nitrogen form influences root growth of sodded creeping bentgrass. Hortsci. 25:932-933.

Garnier, E. and S. Vancaeyzeele. 1994. Carbon and nitrogen content of congeneric annual and perennial grass species: relationships with growth. Plant, Cell Environ. 17:399-407.

Goebel, C.J., M. Tazi, and G.A. Harris.1988. Secar bluebunch wheatgrass as a competitor to medusahead. J. Range Manage. 41:88-89.

Harris, G.A. 1967. Some competitive relationships between Agropyron spicatum and Bromus tectorum. Ecol. Monogr. 37:89-111.

Harris, G.A. 1977. Root phenology as a factor of competition among grass seedlings. J. Range Manage. 30:172-177.

Harris, G.A. and A.M. Wilson. 1970. Competition for moisture among seedlings of annual and perennial grasses as influenced by root elongation at low temperature. Ecol. 51:530-534.

Hart, S.C., J.M. Stark, E.A. Davidson, and M.K. Firestone. 1994. Nitrogen mineralization, immobilization and nitrification, $\mathrm{p}$. 985-1018. In: R.W. Weaver, S. Angle, P. Bottomley, D. Bezdicek, S. Smith, A. Tabatabai, and A. Wollum (eds.) Methods of soil analysis microbiological and biochemical properties, Third edition. Soil Sci. Soc. of Amer., Madison, Wis.

Hassan, M.A. and N.E. West. 1986. Dynamics of soil seed pools in burned and unburned sagebrush semideserts. Ecol. 67:269-272.

Hilton, J.R. and J.A. Thomas. 1986. Regulation of pregerminative rates of respiration in seeds of various weed species by potassium nitrate. J. Exp. Bot. 37:1516-1524

Hironaka, M. 1961. The relative rate of root development of cheatgrass and medusahead. J. Range Manage. 14:263-267.

Huenneke, L.F., S.P. Hamburg, R. Koide, H.A. Mooney, and P.M. Vitousek. 1990. Effects of soil resources on plant invasion and community structure in California serpentine grassland. Ecol. 71:478-491.

Hulbert, L.C. 1955. Ecological studies of Bromus tectorum and other annual bromegrasses. Ecol. Monogr. 25:181-213.

Humphrey, D. and E. Schupp. 2001. Seed banks of Bromus tectorum-dominated communities in the Great Basin. W. North Amer. Natur. 61:85-92.

Jones, T.A., D.C. Nielson, D.G. Ogle, D.A. Johnson, and S.A. Young. 1998. Registration of Sand Hollow Squirreltail germplasm. Crop Sci. 38:286.
Lachat. 1989. Operations manual for the QuikChem automated ion analyzer. Quikchem 12-107-04-1-B (nitrate). Lachat, Milwaukee, Wis.

Lachat. 1990. Operations manual for the QuikChem automated ion analyzer. Quikchem 12-107-06-2-A (ammonium). Lachat, Milwaukee, Wis.

Littell, R. C., G. A. Milliken, W. W. Stroup, and R. D. Wolfinger. 1996. SAS system for mixed models. Cary, N.C: SAS Institute, Inc.

Mack, R.N. and D.A. Pyke. 1983. The demography of Bromus tectorum: variaton in time and space. J. Ecol. 71:69-93.

McIntyre, G.I., A.J. Cessna, and A.I. Hsiao. 1996. Seed dormancy in Avena fatua: Interacting effects of nitrate, water and seed coat injury. Physiol. Plant. 97:291-302.

McKell, C.M., J.P. Robison, and J. Major. 1962. Ecotypic variation in medusahead, an introduced annual grass. Ecol. 43: 686-687.

Meyer, S.E. and P.S. Allen. 1999. Ecological genetics of seed germination regulation in Bromus tectorum L. I. Phenotypic variance among and within populations. Oecologia 120:27-34

Muller, B. and E. Garnier. 1990. Components of relative growth rate and sensitivity to nitrogen availability in annual and perennial species of Bromus. Oecologia 84:513-518.

Paschke, M.W., T. McLendon, and E.F. Redente. 2000. Nitrogen availability and old-field succession in a shortgrass steppe. Ecosystems 3:144-158.

Pons, T.L. 1989. Breaking of seed dormancy by nitrate as a gap detection mechanism. Ann. Bot. 63:139-143.

Poorter, H., C. Remkes, and H. Lambers. 1990. Carbon and nitrogen economy of 24 wild species differing in relative growth rate. Plant Physiol. 94:621-627.

Pyke, D.A. 1990. Comparative demography of co-occurring introduced and native tussock grasses: persistence and potential expansion. Oecologia 82:537-543.

Riba, M., A. Rodrigo, B. Colas, and J. Retana. 2002. Fire and species range in Mediterranean landscapes: an experimental comparison of seed and seedling performance among Centaurea taxa. J. Biogeogr. 29:135-146.

SAS Statistical Analysis Systems. 1999. SAS/STAT User's Guide. Version 8. Cary, N.C: Statist. Anal. Systems Institut.

Sharp, L.A., M. Hironaka, and E.W. Tisdale. 1957. Viability of medusa-head (Elymus caput-medusae L.) seed collected in Idaho. J. Range Manage. 10:123-126.

Shipley, B. and P.A. Keddy. 1988. The relationship between relative growth rate and sensitivity to nutrient stress in twenty-eight species of emergent macrophytes. J. Ecol. 76:1101-1110.

Silverton, J.W. and J.B. Dickie. 1980. Seedling survivorship in natural populations of nine perennial chalk grassland plants. New Phytol. 88:555-558.
Svejcar, T. 1990. Root length, leaf area, and biomass of crested wheatgrass and cheatgrass seedlings. J. Range Manage. 43:446-448.

TeKrony, D.M. and D.B. Egli. 1991. Relationship of seed vigor to crop yield: a review. Crop Sci. 31:816-822.

Trickler, D.L., D.T. Hall, C.D. Franks, S.K. Ferguson, L.B. Campbell, P.J. Savage, and J.E. Brewer. 2000. Soil survey of Tooele area, Utah. U.S. Gov. Printing Office, Washington, D.C.

Westwood, J.H. and C.L. Foy. 1999. Influence of nitrogen on germination and early development of broomrape (Orobanche spp.). Weed Sci. 47:2-7.

Young, J.A. 1992. Ecology and management of medusahead (Taeniatherum caputmedusae ssp. asperum [Simk.] Melderis). Great Basin Natur. 52:245-252.

Young, J.A., R.R. Blank, and W.S. Longland. 1995. Nitrogen enrichmentimmobilization to control succession in arid land plant communities. J. Arid Land Stud. 5S:57-60.

Young, J.A., R.A. Evans, and R.E. Eckert, Jr. 1969. Emergence of medusahead and other grasses from four seeding depths. Weed Sci. 17:376-379

Young, J.A., J.D. Trent, R.R. Blank, and D.E. Palmquist. 1998. Nitrogen interactions with medusahead (Taeniatherum caputmedusae ssp. asperum) seedbanks. Weed Sci. 46:191-195. 